\title{
Structure and Properties of Assimilatory Nitrate Reductase from the Yeast Candida nitratophila
}

\author{
By C. R. HIPKIN,* A. H. ALI AND A. CANNONS \\ Plant and Microbial Metabolism Research Group, School of Biological Sciences, \\ University College of Swansea, Swansea SA2 8PP, UK
}

(Received 14 August 1985; revised 22 January 1986)

\begin{abstract}
$\mathrm{NAD}(\mathrm{P}) \mathrm{H}$ nitrate reductase (EC 1.6.6.2) from the yeast $C$ andida nitratophila has been purified to electrophoretic homogeneity. The concentrated enzyme has a molecular mass of $365 \mathrm{kDa}$ and consists of four subunits each of $95 \mathrm{kDa}$, but appears to dissociate into dimers after dilution. The absorption spectrum of the homogeneous protein is typical of a $b$-type cytochrome and its isoelectric point is pH 5.4. The enzyme utilizes both NADH and NADPH but is more active with NADH. Preincubation of pure enzyme with $\mathrm{NAD}(\mathrm{P}) \mathrm{H}$ and cyanide, but not NAD(P)H and ADP, leads to a reversible redox inactivation of the enzyme. Preincubation with NAD(P)H alone activates the enzyme.
\end{abstract}

\section{INTRODUCTION}

Assimilatory nitrate reductase (NR) has been highly purified from a number of eukaryotic sources including fungi (Guerrero \& Gutierrez, 1977; Pan \& Nason, 1978; Renosto et al., 1981), algae (Solomonson, 1975; Giri \& Ramadoss, 1979; De la Rosa et al., 1980) and higher plants (Fido \& Notton, 1984; Redinbaugh \& Campbell, 1985). In these organisms NR is a multimeric, molybdoflavoprotein, which may differ in subunit mass and composition depending on the source from which it is obtained. Further, in algae and higher plants the preferred electron donor is often NADH whereas in fungi, it is usually NADPH (Pateman \& Kinghorn, 1976; Garrett \& Amy, 1978; Hipkin et al., 1979; Beevers \& Hageman, 1980). Some differences between eukaryotic NR proteins could be of phylogenetic importance and may be related to their mode of regulation in vivo.

During studies of the regulation of nitrate assimilation in yeast we observed that the NR of Candida spp. ( $C$. nitratophila, in particular) was very active. We have purified the enzyme from C. nitratophila to a very high specific activity and describe here some aspects of its quaternary structure and biochemical properties.

\section{METHODS}

Organism and culture. Candida nitratophila (NCYC 556) was obtained from the National Yeast Culture Collection, Norwich, UK. It was grown in $250 \mathrm{ml}$ Erlenmeyer flasks containing $100 \mathrm{ml}$ of the liquid mineral medium described by Ferguson \& Sims (1971), with $1 \%(\mathrm{w} / \mathrm{v})$ glucose as carbon source and either $10 \mathrm{~mm}-\mathrm{NaNO}_{3}$ (nitrate medium) or $10 \mathrm{mM}-\mathrm{NH}_{4} \mathrm{Cl}$ (ammonium medium) as nitrogen source. The $\mathrm{pH}$ of the medium after autoclaving was $5 \cdot 1$. Twenty $100 \mathrm{ml}$ cultures were started by inoculation from stock cultures (maintained on Oxoid malt extract agar plates) into ammonium medium and these were incubated for $16 \mathrm{~h}$ at $28^{\circ} \mathrm{C}$ with orbital shaking at 110 r.p.m. Cultures were then harvested by centrifugation at $500 \mathrm{~g}$, washed with distilled water and resuspended in equal portions into five $180 \mathrm{ml}$ portions of nitrate medium. These nitrate-adapting cultures were then incubated under growth conditions for a further $2 \mathrm{~h}$.

Purification of nitrate reductase (NR) (EC 1.6.6.2). Nitrate-adapted cultures (approximately $20 \mathrm{~g}$ wet weight)

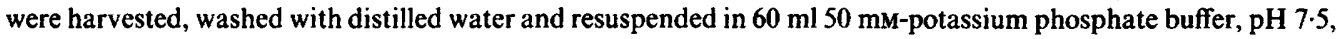

\footnotetext{
Abbreviations: BVH, reduced benzyl viologen; pCMB, p-chloromercuribenzoate; FAD, flavin adenine dinucleotide; FMN, flavin mononucleotide; NR, nitrate reductase.
} 
containing $5 \mu \mathrm{M}$-FAD, $150 \mu \mathrm{M}$-dithiothreitol and $120 \mu \mathrm{M}-\mathrm{Na}_{2}$ EDTA (buffer A). Cell-free extract was prepared by passing this suspension two or three times through a chilled French pressure cell at $100 \mathrm{MPa}$. The homogenate was then centrifuged at $40000 \mathrm{~g}$ for $25 \mathrm{~min}$ at $3^{\circ} \mathrm{C}$ and the supernatant was filtered through glass fibre paper. Subsequent purification of the filtered extract involved at least four sequential affinity chromatography runs using blue Sepharose CL-6B (Pharmacia) and elution with reduced pyridine nucleotides. The filtered extract was loaded $\left(0.4 \mathrm{ml} \mathrm{min}^{-1}\right.$ ) onto a K9/15 column (Pharmacia) containing the blue Sepharose gel equilibrated with buffer A. NR in the crude extract does not bind to the affinity gel at this stage but elutes straight through the column in buffer A. Residual NR in the void volume was eluted with $20 \mathrm{ml}$ buffer A. Active fractions were pooled and the procedure was repeated using a fresh column of blue Sepharose until NR bound to the column and could not be detected in the eluate. The column was then washed with $100 \mathrm{ml}$ buffer A and NR was eluted with $30 \mathrm{ml}$ buffer A containing $0.1 \mathrm{~mm}-\mathrm{NADH}$. Active fractions were pooled, left for $16 \mathrm{~h}$ at $4{ }^{\circ} \mathrm{C}$ and re-loaded onto another fresh column of blue Sepharose, which was washed and eluted with NADH buffer as before. Active fractions were pooled and concentrated by ultrafiltration at $400 \mathrm{kPa}$ through an Amicon PM 30 filter to a volume of 1-2 ml. This concentrate was diluted to $10 \mathrm{ml}$ with buffer $\mathrm{A}$, concentrated again, diluted to $10 \mathrm{ml}$ and re-loaded onto a fresh blue Sepharose column. This was washed with buffer A as before and NR was eluted with buffer A containing $0.1 \mathrm{mM}-\mathrm{NADPH}$. Active fractions were pooled and concentrated as before. With some preparations the highly purified enzyme from this step was chromatographed through a $90 \mathrm{~cm}$ Bio-Gel $1 \mathrm{M}$ (Bio-Rad) column at a rate of $18 \mathrm{ml} \mathrm{h}^{-1}$. Active fractions were pooled and concentrated as before. This final gel filtration step did not increase the degree of purification obtained but removed minor protein bands sometimes observed on electrophoresis gels.

Enzyme assays. Enzyme assay mixtures contained $50-100 \mu \mathrm{g}$ protein from crude extracts or $0 \cdot 25-0 \cdot 5 \mu \mathrm{g}$ protein from purified preparations. NAD(P)H-NR activity was assayed by nitrite production in a volume of $0.7 \mathrm{ml}$ containing $12.5 \mu \mathrm{mol}$ potassium phosphate buffer, $\mathrm{pH} 7.5,2.5 \mathrm{nmol} \mathrm{FAD,} 25 \mu \mathrm{mol} \mathrm{KNO}_{3}, 2.5 \mathrm{mg}$ bovine serum albumin and $0.8 \mu \mathrm{mol} N \mathrm{NADH}$ or NADPH. The assay reaction proceeded for $10 \mathrm{~min}$ at $30^{\circ} \mathrm{C}$ and was terminated by boiling. Tubes were cooled, and, after the addition of $1 \mathrm{ml} 30 \mu \mathrm{M}$-phenazine methosulphate (Scholl et al., 1974), placed in the dark for $10 \mathrm{~min}$. Nitrite was determined colorimetrically by the Griess-Ilosvay reaction as described by Everest et al. (1984). Terminal-NR (BVH-NR) activity was assayed as described above except that assay mixtures contained $0.5 \mu \mathrm{mol}$ benzyl viologen $(\mathrm{BV})$ reduced by the addition of $1.6 \mathrm{mg}$ sodium dithionite and $1.6 \mathrm{mg}$ $\mathrm{NaHCO}_{3}$. Assays were terminated by vigorous mixing, which rapidly oxidized residual dithionite.

$\mathrm{NAD}(\mathrm{P}) \mathrm{H}$-cytochrome $c$ reductase (diaphorase) activity was determined spectrophotometrically at $550 \mathrm{~nm}$. Reaction mixtures $(2.8 \mathrm{ml})$ contained $140 \mu \mathrm{mol}$ potassium phosphate buffer, pH $7.5,14 \mathrm{nmol}$ FAD, 0.5 $\mu$ mol NADH or NADPH, $2.5 \mathrm{mg}$ bovine serum albumin and $8 \mathrm{mg}$ cytochrome $c$ (Sigma, horse heart). Reactions were initiated by the addition of enzyme and activity was calculated from initial reaction rates over a $60 \mathrm{~s}$ period. Affinity constants for the enzyme were calculated from least squares regression analysis of Hanes-Wolfe plots (Bliss \& James, 1966).

Protein determinations. Protein was measured by the method of Bradford (1976), using Bio-Rad protein reagent.

Determination of the molecular mass of NR. This was done by the method of Siegel \& Monty (1966). Values for Stoke's radius $\left(r_{s}\right)$ were determined by gel filtration through Sephacryl S-400, superfine (Pharmacia) and Bio-Gel A-1.5 M (Bio-Rad) in $90 \mathrm{~cm}$ columns, as described by Hipkin et al. (1985). Values for sedimentation coefficient $\left(\mathrm{S} 20_{w}\right)$ were determined by sucrose density gradient centrifugation by a method based on that of Martin \& Ames (1961), as described by Hipkin et al. (1985). The molecular mass of NR was estimated by computing values of $r_{\mathrm{s}}$ and $\mathrm{S} 20_{\mathrm{w}}$ into the Svedberg equation (Siegel \& Monty, 1966).

Electrophoresis. SDS-PAGE was done on $10 \%$ and $12 \%(\mathrm{w} / \mathrm{v})$ vertical slab gels (Laemmli, 1970). Nondissociating electrophoresis was done at $20 \mathrm{~mA}$ for $3-4 \mathrm{~h}$ at $4{ }^{\circ} \mathrm{C}$ in $7 \%(\mathrm{w} / \mathrm{v})$ polyacrylamide gel. NR activity in these gels was measured in $5 \mathrm{~mm}$ slices. Isoelectric focusing was done using an LKB multiphore system and LKB ampholine polyacrylamide plates with a $\mathrm{pH}$ gradient of $3.5-9.5$ at $4{ }^{\circ} \mathrm{C}$, according to the manufacturer's instructions. The cathodic electrode strip was saturated with $1 \mathrm{M}-\mathrm{NaOH}$ and the anodic strip with $1 \mathrm{M}-\mathrm{H}_{3} \mathrm{PO}_{4}$. Electrophoresis was allowed to proceed at $1600 \mathrm{~V}$ for $90 \mathrm{~min}$. NR activity in these gels was measured in $3 \mathrm{~mm}$ slices.

Protein bands on electrophoresis gels were detected by staining with Coomassie brilliant blue $\mathbf{R}$.

Reproducibility of results. All experiments were repeated at least twice and representative results are presented.

\section{RESULTS AND DISCUSSION}

\section{Purification and physical properties of NR from C. nitratophila}

NR was purified after four or five sequential chromatography steps using the affinity gel blue Sepharose CL-6B. During the first run $90 \%$ of the NR activity loaded onto the column eluted without binding. Other proteins present in the crude extract, however, did bind to the gel. During subsequent steps, NR bound to the gel and could be eluted with $0 \cdot 1 \mathrm{mM}-\mathrm{NADH}$. A final 
Table 1. Purification of C. nitratophila NR

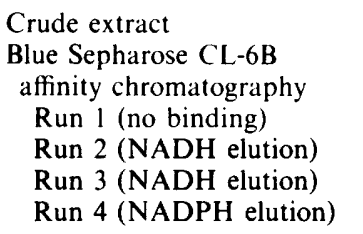

\begin{tabular}{|c|c|c|c|c|c|c|}
\hline & $\begin{array}{l}\text { Vol. } \\
\text { (ml) }\end{array}$ & $\begin{array}{l}\text { Total } \\
\text { protein } \\
(\mathrm{mg})\end{array}$ & $\begin{array}{c}\text { Activity } \\
\left(\mu \mathrm{mol} \mathrm{min}^{-1}\right)\end{array}$ & $\begin{array}{l}\text { Yield } \\
(\%)\end{array}$ & $\begin{array}{c}\text { Specific } \\
\text { activity } \\
{\left[\mu \mathrm{mol} \mathrm{min}^{-1}\right.} \\
\left(\mathrm{mg} \mathrm{protein}^{-1}\right]\end{array}$ & $\begin{array}{l}\text { Purification } \\
\text { (fold) }\end{array}$ \\
\hline $\begin{array}{l}\text { Crude extract } \\
\text { Blue Sepharose CL-6B } \\
\text { affinity chromatography }\end{array}$ & 60 & 727 & 144 & 100 & $0 \cdot 198$ & 0 \\
\hline Run 1 (no binding) & 75 & 397 & 135 & 95 & $0 \cdot 34$ & 2 \\
\hline Run 2 (NADH elution) & 30 & 7.28 & 105 & 73 & $14 \cdot 42$ & 73 \\
\hline Run 3 (NADH elution) & 10 & 1.29 & 75 & 52 & 58.23 & 294 \\
\hline Run 4 (NADPH elution) & 10 & $0 \cdot 276$ & 60 & 42 & $217 \cdot 40$ & 1098 \\
\hline
\end{tabular}

affinity run using $0 \cdot 1 \mathrm{mM}-\mathrm{NADPH}$ to elute the enzyme resulted in a preparation that had been purified by at least 1000 -fold with a specific activity of not less than $200 \mu \mathrm{mol} \mathrm{min}^{-1}$ (mg protein $)^{-1}\left[3 \cdot 3 \mu \mathrm{kat}(\mathrm{mg} \text { protein })^{-1}\right]$. Yields varied between 20 and $50 \%$ with recoveries of $150-$ $300 \mu \mathrm{g}$ NR protein. Sixteen separate batches of $C$. nitratophila extracts were purified by this procedure with similar results. The results of a typical run are shown in Table 1.

Purified NR was not stable during storage in buffer $\mathrm{A}$ at $4{ }^{\circ} \mathrm{C}, 50 \%$ of the enzyme activity being usually lost after $7 \mathrm{~d}$, and was particularly labile to dilution with protein-free buffer. For this reason $2.5 \mathrm{mg}$ bovine serum albumin was included in all enzyme assays to stabilize the enzyme.

The purity and subunit composition of the enzyme were estimated by electrophoresis. Only one protein band was evident on non-dissociating gels and its position coincided with a sharp peak in BVH-NR activity measured in gel slices (Fig. 1). Also, on SDS gels freshly purified enzyme showed one band with a molecular mass estimated as $95 \pm 1.0 \mathrm{kDa}$ (Fig. 2).

The $r_{\mathrm{s}}$ of the freshly purified enzyme was estimated to be $8.5 \mathrm{~nm}$. Older, less active preparations of pure NR gave a lower $r_{\mathrm{s}}(5.4 \mathrm{~nm})$. Values for the $\mathrm{S} 20_{\mathrm{w}}$ of the enzyme were dependent upon the concentration of NR applied to the top of the sucrose gradient; with $200 \mu \mathrm{g}$ protein $\mathrm{ml}^{-1}$ a value of 10.25 was obtained consistently, decreasing to 8.75 (or 7.8 in one experiment) with $50 \mu \mathrm{g}$ protein $\mathrm{ml}^{-1}$. The dilute enzyme also showed a lower $r_{\mathrm{s}}(6.5 \mathrm{~nm})$. When the values $r_{\mathrm{s}}=8.5 \mathrm{~nm}$ and $\mathrm{S} 20_{\mathrm{w}}=10.25$ (i.e. concentrated, freshly purified enzyme) are computed with the Svedberg equation, a molecular mass of $365 \mathrm{kDa}$ is obtained. Given a subunit mass of $95 \mathrm{kDa}$, this species of the NR molecule appears to be composed of four subunits. A molecular mass of about $200 \mathrm{kDa}$ was calculated for the dilute enzyme, which appears to be composed of two subunits. The isoelectric point of the enzyme was pH 5.4. Enzyme activity in gel slices coincided with a major band although the presence of minor, nonactive bands suggested that the enzyme dissociated as it migrated towards the anode (not shown).

The difference spectrum (reduced minus oxidized enzyme) of the pure enzyme indicated absorption maxima for the reduced enzyme at $423 \mathrm{~nm}$ (Soret band), $557 \mathrm{~nm}$ and a broad shoulder centred around $528 \mathrm{~nm}$. The oxidized enzyme showed an oxidized Soret peak at $413 \mathrm{~nm}$ (Fig. 3). From this we infer the presence of cytochrome $b_{557}$ in the enzyme molecule. The $A_{278} / A_{413}$ ratio of the enzyme used in this experiment was $2 \cdot 4$.

Estimations of the molecular mass of eukaryotic NR vary from approximately $200 \mathrm{kDa}$ to $500 \mathrm{kDa}$. Of the more highly purified and well studied enzymes, that of Neurospora crassa appears to have a molecular mass of $290 \mathrm{kDa}$ with two subunits (Horner, 1983), whereas that of Chlorella appears to have a molecular mass of $360 \mathrm{kDa}$ made up of four subunits (Howard \& Solomonson, 1982). The quaternary structure of $C$. nitratophila NR, described here, closely resembles that of Chlorella NR (Howard \& Solomonson, 1982). Moreover, the latter showed that the Chlorella enzyme can exist in various active states of polymerization in vitro, depending on dilution, and they suggested that the active protein may exist as a dimer or a dimer of dimers. 


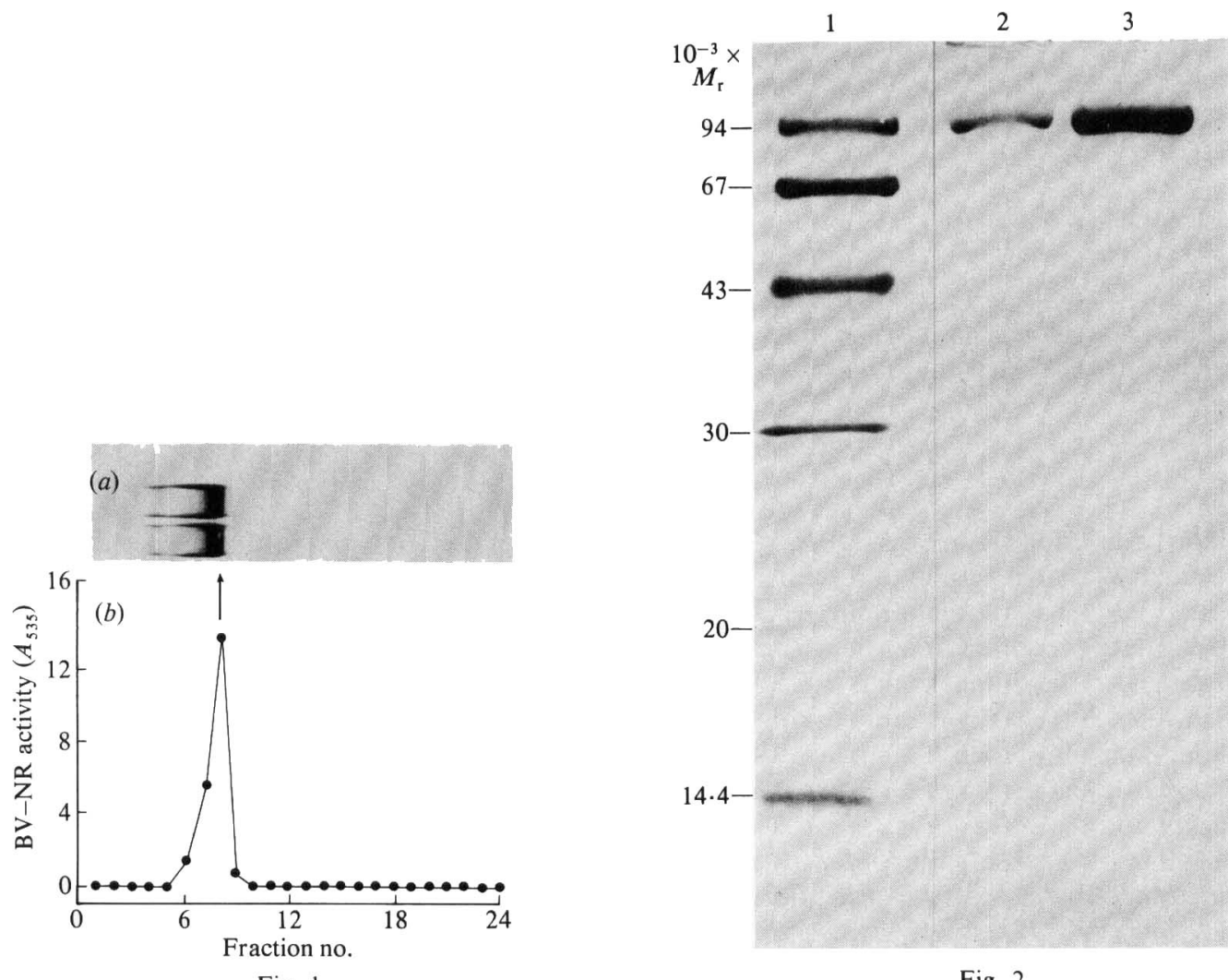

Fig. 1

Fig. 2

Fig. 1. Non-dissociating PAGE of purified $C$. nitratophila NR. Samples containing approx. $40 \mu \mathrm{g}$ pure NR were loaded onto a $7 \%(\mathrm{w} / \mathrm{v})$ polyacrylamide gel and electrophoresed for $3-4 \mathrm{~h}$ at $4{ }^{\circ} \mathrm{C}$. The gel was then divided and half was stained for protein $(a)$. The other half was cut into $5 \mathrm{~mm}$ slices, which were then assayed for BVH-NR activity $(b)$.

Fig. 2. SDS-PAGE of purified $C$. nitratophila NR. Purified NR was electrophoresed on a $12 \%(w / v)$ SDS-polyacrylamide gel and stained for protein. Track 1 contains marker proteins and tracks 2 and 3 were loaded with $25 \mu \mathrm{g}$ and $50 \mu \mathrm{g}$ of pure NR respectively.

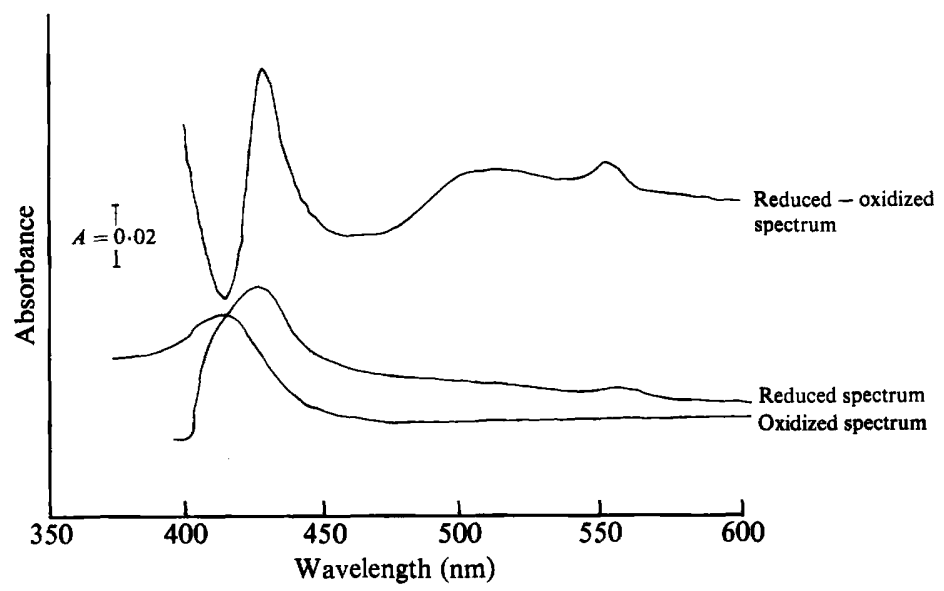

Fig. 3. Absorption spectra of pure $C$. nitratophila NR measured on a Pye-Unicam SP 800 twin beam scanning spectrophotometer. NR was reduced by the addition of a few crystals of sodium dithionite. 
Table 2. Pyridine nucleotide specificity and flavin requirement of $C$. nitratophila NR

Addition* Percentage

NADH

NADH + FMN

$\mathrm{NADH}+\mathrm{FAD} \quad 100 \cdot 0$

NADPH $\quad 18 \cdot 3$

NADPH + FMN 28.4

NADPH + FAD 59.6

* NAD(P)H, $240 \mu \mathrm{M}$; FMN, $5 \mu \mathrm{M}$; FAD, $5 \mu \mathrm{M}$.

$\dagger 100 \% \mathrm{NR}$ activity $=197.8 \mu \mathrm{mol} \mathrm{NO}-\mathrm{min}^{-1}(\mathrm{mg} \text { protein })^{-1}$.

Table 3. Activation and inactivation of C. nitratophila NADH-NR activity

\begin{tabular}{|c|c|c|c|}
\hline $\begin{array}{l}\text { Preincubation } \\
\text { addition* }\end{array}$ & $\begin{array}{l}\text { Percentage } \\
\text { activity }\end{array}$ & $\begin{array}{l}\text { Preincubation } \\
\text { addition* }\end{array}$ & $\begin{array}{l}\text { Percentage } \\
\text { activity } \dagger\end{array}$ \\
\hline $\begin{array}{l}\text { None } \\
\text { NADH } \\
\text { NADPH } \\
\text { ADP } \\
\text { NADH + ADP } \\
\text { NADH + ADP + } \mathrm{Mg}^{2+}\end{array}$ & $\begin{array}{r}100 \cdot 0 \\
140 \cdot 5 \\
115 \cdot 8 \\
98 \cdot 7 \\
145 \cdot 6 \\
139 \cdot 3\end{array}$ & $\begin{array}{l}\text { KCN } \\
\text { NADH + KCN } \\
\text { NADH + KCN }(+ \text { ferricyanide }) \\
\mathrm{KNO}_{3}+\mathrm{NADH}+\mathrm{KCN} \\
\text { pCMB } \\
\mathrm{NADH}+\text { pCMB } \\
\mathrm{NADPH}+\text { pCMB }\end{array}$ & $\begin{array}{r}98 \cdot 0 \\
12 \cdot 3 \\
132 \cdot 3 \\
118 \cdot 2 \\
14 \cdot 3 \\
123 \cdot 3 \\
115 \cdot 8\end{array}$ \\
\hline
\end{tabular}

* Purified NR was preincubated with NAD(P)H or ADP for 60 min at $0{ }^{\circ} \mathrm{C}$, or with $\mathrm{KCN}$ or pCMB for $10 \mathrm{~min}$ at $20^{\circ} \mathrm{C}$. NAD(P)H, $0.3 \mathrm{mM}$; ADP, $0.3 \mathrm{mM} ; \mathrm{MgCl}_{2}, 10 \mathrm{mM} ; \mathrm{KCN}, 3 \mu \mathrm{M}$; ferricyanide, $0.3 \mathrm{mM} ; \mathrm{KNO}_{3}, 5 \mathrm{mM}$. pCMB, $20 \mu \mathrm{M}$.

$+100 \%$ NADH-NR activity $=282 \cdot 1 \mu \mathrm{mol} \mathrm{NO}-\min ^{-1}(\mathrm{mg} \text { protein })^{-1}$.

Our results suggest a similar variation in quaternary structure, based on dimers, for $C$. nitratophila NR. Losses of activity that occur after dilution or storage may result from dissociation of the tetrameric form of the enzyme. The freshly purified and concentrated protein, stabilized with bovine serum albumin, had a very high specific activity and a turnover number of $>1000 \mathrm{~s}^{-1}$.

\section{Pyridine nucleotide specificity and in vitro inactivation/activation of NR}

Unlike the NR of other fungi such as Aspergillus, Neurospora, Penicillium and Sporobolomyces, which are NADPH-specific (Cove \& Coddington, 1965; Garrett \& Amy, 1978; Renosto et al., 1981 ; Ali \& Hipkin, 1985), the NR of $C$. nitratophila could utilize NADH and NADPH (Table 2). However, NR activity was $50 \%$ greater with $\mathrm{NADH}$. Maximum activity required the addition of flavin nucleotide, and FAD was more effective than FMN. Apparent $K_{\mathrm{m}}$ values for pyridine nucleotides were 16.9 $\pm 5.1 \mu \mathrm{M}$ (NADH) and $29.8 \pm 9.7 \mu \mathrm{M}$ (NADPH), and those for nitrate were $120.3 \pm 30.4 \mu \mathrm{M}$ (NADH-NR) and $110.0 \pm 20.7 \mu \mathrm{M}$ (NADPH-NR).

Like the NR of Neurospora and unicellular algae (Garrett \& Greenbaum, 1973; Solomonson $e t$ al., 1973; Hipkin et al., 1979), C. nitratophila NR was subject to a reversible, redox inactivation in the presence of NADH and cyanide. Preincubation with cyanide and NADH inactivated enzyme activity by $88 \%$ and the inactive enzyme was reactivated after treatment with ferricyanide. Addition of cyanide alone did not inactivate the enzyme (Table 3). Addition of nitrate to preincubation mixtures before cyanide and NADH protected the enzyme against inactivation. NR from certain algal sources is subject to a reversible redox inactivation after long term incubation with NAD(P)H or, particularly, with NAD(P)H and ADP (Moreno et al., 1972; Maldonado et al., 1973). The NR of C. nitratophila was not inactivated by such treatment (Table 3); in contrast, preincubation with NADH or NADPH activated NR activity as long as cyanide was absent, the presence or absence of ADP having little effect. Preincubation of the enzyme with pCMB inhibited NR activity by $86 \%$ (Table 3 ), which was prevented when 
Table 4. Activation and inactivation of terminal-NR (BVH-NR) and NADHcytochrome $c$ reductase

\begin{tabular}{lcc}
\multicolumn{1}{c}{ Addition* } & $\begin{array}{c}\text { Percentage } \\
\text { BVH-NR } \\
\text { activity } \dagger\end{array}$ & $\begin{array}{c}\text { Percentage } \\
\text { NADH-cytochrome } c \\
\text { reductase activity } \ddagger\end{array}$ \\
None & $100 \cdot 0$ & $100 \cdot 0$ \\
NADH & $129 \cdot 6$ & $140 \cdot 6$ \\
NADH + KCN & $5 \cdot 5$ & $163 \cdot 4$ \\
pCMB & $102 \cdot 9$ & $2 \cdot 3$
\end{tabular}

* NADH, $0.3 \mathrm{mM}$; KCN, $3 \mu \mathrm{M} ; \mathrm{pCMB}, 20 \mu \mathrm{M}$.

$+100 \%$ BVH-NR activity $=157.6 \mu \mathrm{mol} \mathrm{NO}_{2}^{-} \mathrm{min}^{-1}$ (mg protein) ${ }^{-1}$.

$\ddagger 100 \%$ NADH-cytochrome $c$ reductase activity $=382.8 \mu \mathrm{mol} \mathrm{min}^{-1}(\mathrm{mg} \text { protein })^{-1}$.

NADH or NADPH was added before pCMB. Inhibition by cyanide and NADH was the result of a specific inactivation of BVH-NR activity, whereas pCMB inactivation only inhibited cytochrome $c$ reductase activity (Table 4). The addition of low concentrations of pCMB (4$16 \mu \mathrm{M}$ ) enhanced BVH-NR activity (not shown). Preincubation with NADH, which activated NR activity, enhanced both BVH-NR and cytochrome $c$ reductase activities (Table 4). We do not understand the mechanism of this phenomenon but it is possible that NAD(P)H stabilizes the protein in a more active, catalytic configuration. It is noteworthy that NADPH prevented the decay of NR activity in Aspergillus nidulans extracts (Dunn-Coleman \& Pateman, 1976).

Our principal aim in purifying and characterizing the NR of $C$. nitratophila has been to compare the structure and properties of a yeast NR with that of eukaryotic NR from other sources. Our purified preparations had a high specific activity and a high catalytic activity, which compares with the most highly purified preparations of eukaryotic NR (Pan \& Nason, 1978; Renosto et al., 1981). The yeast enzyme resembles Chlorella NR in many respects but differs in its ability to use both NADH and NADPH as electron donors. We made use of this property when we developed our procedure for purifying $C$. nitratophila NR to homogeneity. Our recent experiments (unpublished results) indicate that several other yeast species possess bispecific NR and that the elution procedure described here may be used in their purification.

\section{REFERENCES}

ALI, A. H. \& HiPkIN, C. R. (1985). Nitrate assimilation in the basidiomycete yeast Sporobolomyces roseus. Journal of General Microbiology 131, 1867-1874.

BeEvers, L. \& Hageman, R. H. (1980). Nitrate and nitrite reduction. In The Biochemistry of Plants, vol. 5, pp. 115-167. Edited by B. J. Miflin. London: Academic Press.

Bliss, G. I. \& JAMES, A. T. (1966). Fitting the rectangular hyperbola. Biometrics 22, 573-602.

BRADFORD, M. (1976). A rapid and sensitive method for the quantitation of micrograms of protein utilizing the principle of protein-dye binding. Analytical Biochemistry 72, 248-254.

Cove, D. J. \& Coddington, A. (1965). Purification of nitrate reductase and cytochrome $c$ reductase from Neurospora crassa. Biochimica et biophysica acta 110, 312-318.

De la Rosa, M. A., Diez, J., Vega, J. M. \& Losada, M. (1980). Purification and properties of assimilatory nitrate reductase (NAD(P)H) from Ankistrodesmus braunii. European Journal of Biochemistry 106, 249-256.

Dunn-Coleman, N. S. \& Pateman, J. A. (1976). The regulation of nitrate reductase in the fungus $A$ spergil- lus nidulans. Biochemical Society Transactions 3, 531533.

Everest, S. A., Hipkin, C. R. \& Syrett, P. J. (1984). The effect of phosphate and flavin adenine dinucleotide on nitrate reductase activity of some unicellular marine algae. Journal of Experimental Marine Biology and Ecology 76, 263-273.

Ferguson, A. R. \& Sims, A. P. (1971). Inactivation in vivo of glutamine synthetase and NAD-specific glutamate dehydrogenase: its role in the regulation of glutamine synthesis in yeasts. Journal of General Microbiology 69, 423-427.

Fido, R. J. \& NotTon, B. A. (1984). Spinach nitrate reductase: further purification and removal of 'nicked' sub-units by affinity chromatography. Plant Science Letters 37, 87-91.

GarretT, R. H. \& AMY, N. K. (1978). Nitrate assimilation in fungi. Advances in Microbial Physio$\log y 18,1-65$.

Garrett, R. H. \& Greenbaum, P. (1973). The inhibition of the Neurospora nitrate reductase complex by metal binding agents. Biochimica et biophysica acta 302, 24-32.

GiRI, L. \& Ramadoss, C. (1979). Physical studies on 
assimilatory nitrate reductase from Chlorella vulgaris. Journal of Biological Chemistry 254, 1170311712.

Guerrero, M. G. \& Gutierrez, M. (1977). Purification and properties of the $\mathrm{NAD}(\mathrm{P}) \mathrm{H}$ : nitrate reductase of the yeast Rhodotorula glutinis. Biochimica et biophysica acta 482, 272-285.

Hipkin, C. R., SYRetT, P. J. \& Al-Bassam, B. A. (1979). Some characteristics of nitrate reductase in unicellular algae. In Nitrogen Assimilation of Plants, pp. 309-312. Edited by E. J. Hewitt \& C. V. Cutting. London: Academic Press.

Hipkin, C. R., Hermann-Smith, J. A. \& Syrett, P. J. (1985). The role of nitrate, photosynthesis and protein turnover in the formation of nitrate reductase in the nit $A$ mutant of Chlamydomonas. Biochimica et biophysica acta 838, 191-196.

HoRnER, R. D. (1983). Purification and comparison of nit- 1 and wild type NADPH:nitrate reductases of Neurospora crassa. Biochimica et biophysica acta 744, 7-15.

Howard, W. D. \& Solomonson, L. P. (1982). Quaternary structure of assimilatory NADH : nitrate reductase from Chlorella. Journal of Biological Chemistry 257, 10243-10250.

LAEMMLI, U. K. (1970). Cleavage of the structural proteins during the assembly of the head of the bacteriophage T4. Nature, London 227, 680-685.

Maldonado, J. M., Herrera, J., Paneque, A. \& LOSADA, M. (1973). Reversible inactivation by NADH and ADP of Chlorella fusca nitrate reductase. Biochemical and Biophysical Research Communications 51, 27-33.

MARTIN, R. G. \& AMES, B. N. (1961). A method for determining the sedimentation behaviour of enzymes: application to protein mixtures. Journal of Biological Chemistry 236, 1372-1379.

Moreno, C. G., Aparicio, P. J., Palacian, E. \&
LOSADA, M. (1972). Interconversion of the active and inactive forms of Chlorella nitrate reductase. FEBS Letters 26, 11-14.

Pan, S. \& NASON, A. (1978). Purification and characterization of homogeneous assimilatory reduced nicotinamide adenine dinucleotide phosphate-nitrate reductase from Neurospora crassa. Biochimica et biophysica acta 523, 297-313.

Pateman, J. A. \& Kinghorn, J. R. (1976). Nitrogen metabolism. In The Filamentous Fungi, vol. 2, pp. 159-237. Edited by J. E. Smith \& D. R. Berry. London: Edward Arnold.

Redinbaugh, M. G. \& Campbell, W. H. (1985). Quaternary structure and composition of squash NADH:nitrate reductase. Journal of Biological Chemistry 260, 3380-3385.

Renosto, F., Ornitz, D. M., Peterson, D. \& Segel, I. H. (1981). Nitrate reductase from Penicillium chrysogenum. Journal of Biological Chemistry 256, 8616-8625.

Scholl, R. L., Harper, J. E. \& Hageman, R. H. (1974). Improvements of the nitrite color development in assays of nitrate reductase by phenazine methosulfate and zinc acetate. Plant Physiology 53, 825-828.

SiEGEL, L. M. \& MoNTY, K. J. (1966). Determination of molecular weights and frictional ratios of protein in impure systems by use of gel filtration and density gradient centrifugation. Application to crude preparations of sulphite and hydroxylamine reductases. Biochimica et biophysica acta 112, 346-362.

Solomonson, L. P. (1975). Purification of NADHnitrate reductase by affinity chromatography. Plant Physiology 56, 853-855.

Solomonson, L. P., Jetschmann, C. \& Vennesland, B. (1973). Reversible inactivation of the nitrate reductase of Chlorella vulgaris Beijerinck. Biochimica et biophysica acta 381, 32-43. 